\title{
Ecological Consciousness and Self-Realizationan Identification: A Step towards Spiritualistic World
}

By Dr. Mayuri Barman

Pandu College

Abstract- The most dangerous tendency of the present human generation is to enjoy every aspect of life selfishly which leads to serious threat to an environment. From the very beginning man was never a solitary creature in the planet where the relationship between humans and nature is one of the most fundamental issues we face and must deal with today. A universal holistic approach is needed, which may develop ecological consciousness among us. Many religions, scriptures can help to build a model of ecological consciousness. The importance of ancient Indian religious practices shows that human beings are an integral part of nature, and should, therefore, naturally understand the framework of life. At present human society is misled by the false attraction of the materialistic life, so to realize his true 'self ,' one has to get out of this false notion that human society is the only proprietor of the world. The 'Bhagavad-Gita' nicely describes detachment from materials activities to the transcendental activities with realizing our true 'self.' Warwick Fox and Arne Naess's 'Self Realization' shows how a person who Is selfrealized and well-identified with the non-human world, will behave in harmony with nature, acting from inclination rather than duty.

Keywords: environmental crisis, holistic, ecological consciousness, scriptures, self- realization.

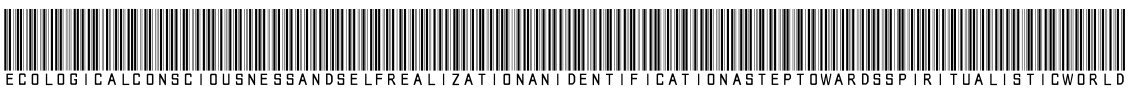

Strictly as per the compliance and regulations of:

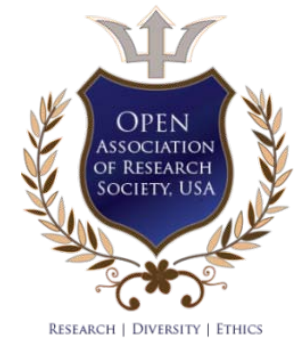

(c) 2020. Dr. Mayuri Barman. This is a research/review paper, distributed under the terms of the Creative Commons AttributionNoncommercial 3.0 Unported License http://creativecommons.org/licenses/by-nc/3.0/), permitting all non commercial use, distribution, and reproduction in any medium, provided the original work is properly cited. 


\title{
Ecological Consciousness and Self-Realization- an Identification: A Step towards Spiritualistic World
}

\author{
Dr. Mayuri Barman
}

\begin{abstract}
The most dangerous tendency of the present human generation is to enjoy every aspect of life selfishly which leads to serious threat to an environment. From the very beginning man was never a solitary creature in the planet where the relationship between humans and nature is one of the most fundamental issues we face and must deal with today. A universal holistic approach is needed, which may develop ecological consciousness among us. Many religions, scriptures can help to build a model of ecological consciousness. The importance of ancient Indian religious practices shows that human beings are an integral part of nature, and should, therefore, naturally understand the framework of life. At present human society is misled by the false attraction of the materialistic life, so to realize his true 'self ; one has to get out of this false notion that human society is the only proprietor of the world. The 'Bhagavad-Gita' nicely describes detachment from materials activities to the transcendental activities with realizing our true 'self.' Warwick Fox and Arne Naess's 'Self Realization' shows how a person who Is self-realized and well-identified with the non-human world, will behave in harmony with nature, acting from inclination rather than duty.
\end{abstract}

Keywords: environmental crisis, holistic, ecological consciousness, scriptures, self- realization.

\section{INTRODUCTION}

T he current capitalist economy is ego-centric. Everyone is structured to satisfy the needs of an individual. What needed is a deeper shift in consciousness so that we begin to care and not only for ourselves but for the entire ecosystem. Therefore, the economic imperatives of our time are need of an evolution of our ecological consciousness and selfrealization. Arne Naess, founding father of environmental movement, developed his own ecological philosophy, which he called "Ecosophy." "By an ecosophy, I mean a philosophy of ecological harmony or equilibrium."( Naess, 1986).

\section{PROBLEM}

The environment is an integrated system in which all its elements act and react in such a way that a balance is always maintained. The strains of the ecological crises are so apparent that the task of preserving the environment is a must.

Author: Asstt. Prof. (Senior Grade), Dept. of Philosophy, Pandu College, Guwahati-781012, Assam. e-mail: mayuree.bn@gmail.com

\section{Objectives}

In this paper, 'Self-realization' and 'Ecological Consciousness' can develop to safeguard against cruelty to all creatures. 'Self-realization' denotes the realization of the organic wholeness as well as some sort of 'rectification' of ourselves. Ecological consciousness for the betterment of society is needed that can create ecological balance. A universal holistic approach which draws from religious or cultural values and beliefs may develop ecological consciousness among us. There are many religions, scriptures, prove to be helpful in building a model of ecological consciousness.

\section{Result and Discussion}

a) Ecological Consciousness in the Vedic period and Bhagavad-Gita

Starting from the Vedas, all the way to the present, respect for all is a capsule in the context of "Vasudhaiv Kutumbakam", that is the whole world is one family. The four Vedas are full of Hymns, which explicitly advocate the supremacy of different natural power. The ancient religious practices show that human beings are connected with nature and every individual self merged with other self.

In the Atharva Vedas (Prithvi Sukta, Slok No. 12), the Vedic seer solemnly declares the enduring filial allegiance of humankind to Mother Earth. Here, Nature has been described as 'O Mother Earth.' The Vedic Hymn to the Earth, the Prithvi Sukta in Atharva Veda, is one of the oldest evocative environmental invocations. "The Earth is not for human beings alone, but also all other bipeds and insects and other creatures." (Atharva Veda 12.115). The Vedic man was nature cantered for him nature and its phenomena were part of eternal divine design. ( The Hymns of Atharva Veda, 2009).

The entire earth is continual by a harmonious cosmic principle, the operation of immutable laws. The laws of unity in nature are known as 'Rta' or cosmic order in the Vedic system. It is the self-regulative law of harmony. It is uncongenial power, the underlying regulator of all life on earth at the natural and human level.

At present human society is being misled by leaders who are blind, for they do not know the aim and 
objective of human life, which is "Self-Realization". According to Vedic civilization, the perfection of life is to realize one's relationship with the Supreme Personality of Godhead. (The Science of Self-Realization, Swami Prabhupada, 1968).

\section{BhagaVAD- Gita}

In the "Bhagavad-Gita, which is accepted by all authorities in transcendental science as the basis of all Vedic knowledge, we understand that not only human beings but all living entities are parts and parcels of God. So, now the question arises- Why are human beings given or better chance to lead a comfortable life by the Laws of Nature? The answer describes as we are given this human form, not just to lead a comfortable life, but to attain the highest perfection of life. The 'Bhagavad Gita' very vividly describes how a spirit soul, by the laws of nature, takes his birth and gets a suitable body, and sense organs for enjoying matter in the material world. The human body is an excellent vehicle by which we can reach eternal life. In our present material consciousness, we are attached to the sensual material conception of life, but his conception can be removed at once by realizing our true self. By realizing our true self, we can give equal rights to every species of this ecosystem to live freely in this biosphere. (The Science of Self-Realization, Swami Prabhupada, 1968).

The fifteen chapters of the Bhagavad-Gita (15.3.4) very nicely describe detachment from material activities to the transcendental activities with realizing our true self:

"na rupam_asyeha tathopalabhyate nanto no cadir na ca sampratistha asvattham enam su-virudha mulam asanga-sastrena drdhana chittva"

"The real form of this Banyan tree cannot be perceived in this world. No one can understand where it ends, where it begins, or where its foundation is. But with determination, one must cut down this strongly rooted tree with the weapon of detachment." By searching in this way, one understands the false reflection of reality, and by knowledge, one can cut off. The connection and detached automatically from this material extension and realize the true self. As long as a human being is in this dark material world, he is in conditional life, but as soon as he reaches the spiritual sky by cutting through the false, perverted tree of this material world, he becomes liberated. So, to realize his true self, one has to get out of this false notion that human society is the only proprietor of this world. These faulty associations bind one to this material world. (The Science of SelfRealization, Swami Prabhupada 1968). describes:-
"Nirmana moha jita sanga dosa

Adhyatma-nitya vinivrtta kamah

Dvandvair vimuktah sukla duhkha samjnair

gacchantry amudhah padam avyayam tat."

"Those who are free from false prestige, illusion and false association, who understand the eternal, who are done with material lust, who are freed from the dualities of happiness and distress, know how to surrender unto the supreme person." (BhagavadGita, 15.6)

Keeping this perspective in mind, we find that Vedic worship is nothing but environmental worship where ecological consciousness developed by showing gratitude towards them. Thus, acceptance of sentimental relations between man and environment is a hallmark of the Vedic concept. Feeling of love and attachment towards the environment, expression of belief, gratitude, and sacrifice in special circumstances for environmental conservation and true sentiments which will help us to grow our 'Ecological Consciousness.' Many concepts of Aryan lifestyle and philosophy, despite being old, are still relevant and useful today. The most famous sayings like Ekom Sad Vipra Bahudha Vadanti,' 'Isha Vasyamidam Sarvam,' 'Vasudhaiva Kutumbakam,' 'Sarve Bhavantu Sukhina,' have reflected in the ideas like unity in diversity, live and let live, simple living and high thinking. Thus, human thought towards environment has been inspired by these Vedic principles, which are refined as well as broad in meaning.

\section{Spiritualistic Aspect: Arne Naess's Holistic Approach}

In modern times, humanity gets embedded in materialistic ambitions selfish motives and become insensitive towards ecological surroundings. Arne Naess arises to find out a solution to our current disconnectedness with nature with his concept of ecological self. His view on ecological self is the light of the process of identification and the idea of selfrealization, to understand the asymmetrical relationship among human beings and nature. His new scientific, philosophical - religious approach claims for a new treatment for the Earth and develops a process to show the meaning and truth in our lives. Arne Naess's theory of 'Deep-Ecology' is a holistic approach to facing environmental problems that bring together thinking, feeling, spirituality, and action. This approach makes everyone connected where we can move from seeing ourselves as part of the earth, along with other living beings. It points towards the development of spirituality, a higher consciousness that would recognize and integrated spiritual values towards nature.

Now, the question arises - what will be the 'way of thinking'? Thinking built on the spiritual aspect, which 
implements that we see ourselves involved, can give our lives aspirations beyond material success. If we see ourselves involved, then a deep ecological approach to spirituality might emphasize our relationship with this larger whole. This life-saving spirituality enables one to face and handle environmental problems. Thus, deep ecology plays a vital role in society from anthropocentric ethic to eco-centric view, which rejects human as the center of the society. Now, the second question comes to our mind - How the real ecological consciousness includes?

Naess in reply to this question as he tends to focus on this connection between humans and nature as a way to justify the development of ecological consciousness. Thus, the real ecological consciousness includes both anthropocentric and ecocentric components. Regarding the phenomenon of life, three basic ideas on Deep ecology are ----

1. Firstly, Deep ecology not only asks deeper questions about our relationship with the world around us but also look for the solutions to what is causing the problems around us.

2. Secondly, the attempt to replace Anthropocentric forms of thinking, valuing, and acting with ecocentric forms of thinking, valuing, and acting.

3. Thirdly, cultivating a particular kind of approach to our relationship with the world around us that Arne Naess refers to as "Self-Realization."

\section{Vil. Arne Naess \& Warwick fox VieW}

a) The concept of 'Self-Realization:- An identification

'Self' is the outcome of an identification process

in which the individual grows to identify with others. Traditionally, the self develops through 3 stages-from ego to social life, comprising the ego and from there to metaphysical self comprising the social self. With the growing maturity and identification with others, the self is widened and deepened. (Arne Naess, 1989).

Both the selves with a capital ' $S$ ' with a meaning to the India atman and small ' $s$ ' meaning individual self are distinguished by Naess. Self is spelled with a capital ' $S$ ' to indicate that it is an enlarged sense of self, not a narrow sense of self. The term 'self-realization' also carries an exclamation mark to mean "do it" - that is, "realize a larger sense of self." The question, therefore, arises in our mind - "how are we to realize as wide and deep a sense of self as possible"? For Naess, the answer is through the process of coming to a full sense of commonality with the world around us. Thus Naess says, "Every living being is connected intimately and from this intimacy follows the capacity of identification and as its natural consequence, the practice of nonviolence."(Deep Ecology and Virtue Ethics, Issues 26, Warwick Fox.).Thus, the personal attempt to cultivate wider and deeper sense of identification with the world around us must certainly approach to virtue ethics.
So, when Arne Naess objects to ethics saying "Just as we do not need morals to make us breathe....... so if your 'self' in the wide sense embraces another being you need no moral exhortation' to show care ..... You care for yourself without feeling any moral pressure to do it." (Deep Ecology and Virtue Ethics, Issues 26, Warwick Fox.).

On the other hand, a person who is self-realized and well-identified with the nonhuman world will perform from inclination rather than duty as Immanual Kant gave a pair of concepts - Moral act and beautiful act. Moral acts are always motivated by moral laws, and it becomes our moral duty to perform it whether we like it or not. Sometimes it goes against our inclination, but we are bound to do it by our respect for moral law. If we do something only because of moral law, then the outcome our satisfaction decreases. And if we do what is right with our inclination, then it turns into a beautiful act. So, Arne Naess says that people should take environmental affairs as a 'beautiful act' rather than the 'moral act.'

Warwick Fox explains very distinctly about a person who realized his self. A 'Self-Realized' individual would not experience confusion over what is his or her own body or person and what is a sparrow, tree, or stone.

"What is being emphasized is the tremendously common experience that through the process of identification my sense of self can expand to include the tree even though I and the tree remain physically separate." (W.Fox. 1990a, p.81).

Therefore Fox's analysis of identification of the self is deeper and wider. "How does one realize, in this worldly sense, as expansive a sense of self as possible? Fox's simple answer is through the process of "identification." (Fox. 1990b, p. 249).

By identification, Fox means the experience of commonality between my self and the world. An ecologically sound life would be one that sustains the widest and deepest possible identification." (Fox 1990 b, p. 249).

\section{Vili. Conclusion}

The appearance of ecological consciousness and self- realization is a turning point in today's society from the anthropocentric mechanism to eco-centric holism. The presence of ecological crisis requires a big change in our form of life. Exploring our ecological self, our life can be enhanced through increased selfrealization, and this can be realized by replacing anthropocentric thinking to eco-centric forms of thinking. By diminishing of 'G' from 'ego,' throw away egoism to receive altruism, the self should reach ' $c$ ' that is 'eco.' This ecological self feels a strong bond with the natural setting around her. Naess expresses the feelings of ecological self as "My relation to this place is part of myself. If this place is destroyed, something in me is 
destroyed" (Naess 1986, 231). Therefore, the self has a major role in the identification and, finally the realization of our relationship with nature.

Naess wrote, "Moral actions are motivated by acceptance of moral law, and manifest themselves clearly when acting against inclination" (Naess 1989, 85).

Thus, if we act rightly towards the environment by inclination and say we do not need to follow moral law as "Morality is too narrow, too patronizing and too open" (Naess, 1993, 71).

\section{References Références Referencias}

1. Arthava Veda.

2. Bhagavad- Gita.

4 3. Fox, Warwick. "Towards a Transpersonal Ecology", Sunny Press, London \& Shambala, 1990.

4. Mathew, Freye. "Value in Nature and Meaning in Life". Newyork, Oxford University, 1995.

5. Naess, Arne. "The Shallow and the Deep Long Range Ecology Movement." Cambridge University Press, 1973.

6. Naess, Arne. "The Deep Ecology Movement: Some Philosophical Aspects, Philosophical Inquiry". Shambhala, Boston \& London, 1986.

7. Naess, Arne. "Self- Realization: An Ecological Approach to Being in the world". The Trumpeter: Journal of Ecosophy, 1987.

8. Naess, Arne. "Ecology, Community and Lifestyle". Cambridge University Press, UK, 1989.

9. S.Subbarao, "Ethics of Ecology and Environment", Rajat Publication, New Delhi, 2001.

10. Session, George.Deep Ecology for the $21^{\text {st }}$ Century, Shambala Publication, Boston and London, 1995. 